\title{
Patience, Self-Control and the Demand for Commitment: Evidence from a Large-Scale Field Experiment
}

\author{
Sule Alan ${ }^{1}$ \\ Department of Economics \\ University of Essex \\ Seda Ertac \\ College of Administrative Sciences and Economics \\ Koc University
}

September 2014

\begin{abstract}
:
Patience and self-control are important non-cognitive skills that are associated with favorable educational, economic and social outcomes. This paper provides empirical evidence to inform discussions on possible educational interventions to make children more forward-looking or less present-biased, by putting forward a way to identify self-control problems in children and exploring the role of commitment devices in mitigating such problems. We report results from an experiment that measures planned allocations, the demand for a commitment device, and actual choices in the context of chocolate consumption over two days. The experiment is conducted as part of a large field study on children's preferences, which allows us to correlate behavior with variables related to the subjects' socio-economic background and educational environment, as well as preference parameters elicited through other tasks and surveys. We find a large demand for commitment among children. In addition, we identify important correlations between patience, commitment demand and time inconsistency, as well as student-specific personality traits and outcomes such as school success.
\end{abstract}

Keywords: Patience, self-control, commitment, intertemporal choice, experiments.

JEL Codes: C93, D91.

\footnotetext{
${ }^{1}$ Corresponding author: Sule Alan: Department of Economics, University of Essex, Colchester, CO79AX, UK, (Email: salan@essex. ac.uk, Phone: +44 (0) 1206 872707), Seda Ertac: Department of Economics, Koc University Rumeli Feneri Yolu, Sariyer, Istanbul 34450 (Email: sertac@ku.edu.tr, Phone: +90(212)3381880). Funding for this study was partially provided by the ING Bank of Turkey as part of their corporate social responsibility program. We are grateful to conference participants at the 2013 workshop on "Self-control, Self-regulation and Education" at Aarhus University for helpful comments. Elif Kubilay, Nergis Zaim, Banu Donmez, Enes Duysak, Emre Karabulutoglu and Aslihan Tutuncu provided excellent research assistance. Ertac also thanks Koc University and the Turkish Academy of the Sciences (TUBA-GEBIP program) for support. Alan thanks European Investment Bank Institute for support. All errors are our own.
} 


\section{Introduction:}

Heterogeneity in time preferences and the ability to delay gratification by resisting temptation (selfcontrol) is likely to account for much of the observed dispersion in many individual choices and outcomes. These include but are not limited to educational attainment, savings, borrowing, wealth accumulation, and health-related outcomes such as obesity and addiction ${ }^{2}$. Preferences aside, lack of selfcontrol can be very costly for individuals. For this reason, we observe various forms of formal and informal commitment mechanisms demanded by individuals to help stick to plans and curb short-term temptations for future rewards. There is now a sizeable theoretical and empirical literature providing insights and evidence on the prevalence of self-control (or lack thereof) and the demand for commitment devices (see Bryan et al (2010) for an extensive review of this literature). This literature focuses mainly on adult behavior within the context of savings, insurance and health-related issues such as smoking or exercise. In this paper, we study patience, self-control and the demand for commitment in children, and in the context of consumption of a temptation good, chocolate.

Studying children's preferences has recently become an important research agenda for economists, for multiple reasons. First, there is evidence that the childhood period is important for the formation and development of a crucial set of preference parameters, which could have persistent effects in adulthood (e.g. Moffitt et al. (2011)). As is the case in adults, experimentally elicited traits seem to be predictive of many important choices and outcomes of children and adolescents as well. In the particular context of time preferences, Sutter et al. (2013) find that impatience in adolescents is related with a higher likelihood of using alcohol and cigarettes, a higher body mass index and more disciplinary conduct violations at school, in addition to a lower propensity to save. Castillo et al. (2011) correlate experimentally-elicited patience with school performance and find that more patient students are more successful. Moreover, preferences in childhood can have long-term implications. In a study that links survey-based time preference at the age of 13 to administrative register data, Golsteyn et al. (2013) document a significant negative relationship between high discount rates and performance in school, health, labor market outcomes and lifetime income. Similarly, in a set of longitudinal studies in psychology, stemming from the widely known "marshmallow test", preschoolers who were able to resist the temptation of marshmallows as a child were found to be more cognitively and socially competent as adults (e.g. Mischel et al., 1989).

\footnotetext{
${ }^{2}$ See Fuchs (1982), Laibson (1994), Laibson et al (1998), Bickel et al (1999), Della Vigna and Paserman (2005), Heckman et al (2006), Meier and Sprenger (2010), Karlan and Zinman (2012), Finke and Huston (2013).
} 
Given the strong correlations between childhood preferences and lifetime outcomes, the issue of malleability of key non-cognitive skills such as self-control in childhood through education has been a focus of interest for academics as well as policymakers (e.g. US Department of Education Report, 2013, Carneiro and Heckman (2003), Knudsen et al (2006), Cunha and Heckman (2008). The idea of malleability is particularly important for designing educational policies, since in addition to the family, the classroom can provide an environment where these skills can be taught and developed. In the particular case of self-control and patience, such training can aim to: (1) emphasize the benefits of forward-looking behavior, (2) improve awareness of biases in intertemporal decision-making, increase sophistication, and present strategies such as commitment devices to cope with self-control problems. ${ }^{3}$ Such early interventions can both have immediate impact on educational achievements through school success and behavioral changes, and have large long-term returns on social and economic outcomes.

In line with this background, the current paper studies decision-making over time as part of an ongoing field experiment involving a large number of elementary school children aged 9. We report results from a multi-day experiment to study intertemporal allocation decisions, the demand for commitment and actual consumption, using a novel incentivized task that involves an attractive consumption good for children, chocolate. We first elicit a planned allocation of an endowment of chocolates, over two consecutive consumption periods that are one week into the future. We then offer a commitment device: a locked chocolate box whose contents cannot be consumed before the 2 nd consumption period. Finally, we observe how much the child actually consumes, when the first consumption period arrives. We supplement these data with the choices of the same children in an alternative discounting task (either a multiple price list or a convex time budget task) in order to explore patience, time inconsistency and the demand for commitment across different discounting tasks, within person. In addition to the behavioral measures we collect, we have access to information about the children, which comes from a teacher questionnaire that includes measures such as school success, teacher-assessed intelligence and family wealth for each child. We also have a survey for children, which elicits personality/temperament measures as potential correlates of behavior.

Our study contributes to several research avenues within the time preference literature. First of all, we study commitment device take-up at a young age. While patience and self-control/temptations have been studied in children (Bettinger and Slonim (2007), Castillo et al. (2011), Bucciol et al. (2011)), this is the first study, to our knowledge, that analyzes sophistication in the context of intertemporal decision-making in children. This question is important because it can suggest implications for tools or commitment

\footnotetext{
${ }^{3}$ Alan and Ertac (in progress) study the impact of such an educational intervention module on intertemporal decision-making within a randomized-controlled framework.
} 
devices that can be offered to children to encourage forward-looking behavior. There is no doubt that lack of self-control can be detrimental to a child's physical, social and intellectual development. It is therefore crucial to pin down possible mechanisms that can mitigate the undesired consequences of self-control problems and to provide empirical evidence about the performance of these mechanisms to inform education policy.

Second, we are able to correlate patience and commitment device take-up in the consumption task with patience and time inconsistency variables from other tasks. ${ }^{4}$ This allows us to both study the relationship between patience and sophistication in a richer way, and to explore whether there is an underlying "time preference" parameter that manifests itself in different tasks. Therefore, from a methodological perspective, our data contributes to the recent literature that examines the within-person, across-task consistency of preferences 5 . Finally, we are able to analyze the correlates of patience and self-control, as well as answer the question of whether time preference, at the quite early age of 9 years-old, can already impact important outcomes such as behavior and success in school.

Our main results are as follows: Apart from observing a significant propensity to smooth consumption over time, we find a high demand for commitment among our 9 year-olds. Children who are free to choose end up consuming more than their planned amount on average, indicating present bias. We find a close relationship between discounting in other tasks and our consumption task. Children who are more patient in the time tasks: (1) make more patient consumption plans, (2) are more likely to take-up the commitment device. In terms of dynamic consistency, children who can be identified as "increasingly impatient" (children who behave less patiently in decisions that are further into the future) are less likely than other types to take up commitment.

We also identify important relationships with gender, school success, family wealth, and personality variables. Consistently with Bettinger and Slonim (2007) and Castillo et al. (2011), we find boys to be less patient in their plans. While there is no gender difference in the propensity to take-up commitment, boys that do so lock more chocolates than girls. Our experimental measures also have an important relationship with school success: successful students tend to make more patient plans, lock fewer chocolates when they demand commitment, and exhibit lower present bias on the actual day of

\footnotetext{
${ }^{4}$ While commitment devices have been studied in various contexts there is not much evidence on the correlation of time inconsistency and commitment demand, within person. An exception is Ashraf et al (2006), who find that women who exhibit hyperbolic discounting behavior in a survey task are more likely to take-up a commitment savings product.

${ }^{5}$ See, for example, Blanco et al. (2011) in the context of other-regarding preferences and Anderson and Mellor (2008) in the context of risk preferences. Burks et al. (2012), on the other hand, pit different time tasks against each other to measure their performance in predicting behavior.
} 
consumption. Finally, we identify some results on personality, that speak to the recent literature on the importance of personality traits for economic behavior (e.g. Borghans et al (2008), Becker et al. (2012)): for example, the lack of an ability to suppress inappropriate urges (inhibitory control) and to perform unwanted tasks (activation control) predict impatience and present bias, respectively, in our experimental task. These results collectively suggest that teacher assessments and personality tests can be used together for identifying the nature of the heterogeneity in terms of self-control problems. Such information provides a valuable input into designing educational interventions targeted towards specific groups of children.

The plan of the paper is as follows: Section 2 describes our design and procedures in detail, Section 3 presents our results, and Section 4 concludes.

\section{Experimental Design and Procedures:}

Our unique data come from a field experiment involving a large number of elementary schools in various districts in Istanbul, Turkey, which aims to study intertemporal choices as well as cognitive and noncognitive skills. The study was done under the approval of the Turkish Ministry of Education and the local IRB, during class time. We use a classroom environment, which helps us greatly reduce transactions costs and payment risk that might be relevant in experiments that involve dynamic consumption. Parental informed consent was obtained for all participants whose data are reported in the paper. The actual data collection, including surveys and incentivized elicitation tasks, were done by visiting each classroom for at least three lecture hours and re-visiting the same classrooms for one lecture hour exactly one week after. Below, we explain the theoretical background, the design and procedures of the consumption experiment, and the other decision tasks we use as correlates.

\subsection{Theoretical Background}

The standard intertemporal allocation model of consumption assumes exponential discounting. This model implies time consistent choices, in the sense that the decision-maker never deviates from a previously made consumption plan. Given the difficulties of such a model in explaining observed biases in intertemporal choice, ranging from savings to health-related behavior (see, for example, DellaVigna (2009) for a review), models that can capture dynamic inconsistency have been proposed. One such model that has been commonly used in the literature is the quasi-hyperbolic discounting (beta-delta) model (Laibson (1997)), which nests exponential discounting as a special case. In this model, discounting between two periods depends not only on the delay between the two periods, but also on when the sooner reward comes. This leads to two possible types of dynamic inconsistency. One is "increasing patience" 
(consistent with hyperbolic discounting), where the decision-maker makes more patient choices in an intertemporal allocation problem as the dates are shifted to the future, with the same delay. This is because the current consumption period holds an extra utility weight (present bias), which pushes the person to consume more today than planned before, exhibiting a self-control problem. The other type of bias is "decreasing patience", consistent with hypobolic discounting. In this case, the decision-maker makes less patient choices as intertemporal allocation alternatives with the same delay are shifted further into the future.

Depending on whether individuals are aware of their dynamic inconsistency, they can be classified as sophisticated or naïve (e.g. O'Donoghue and Rabin (2001)), where the former could take measures to correct for the bias. One important such measure is taking up a commitment device that can help the individual stick to the plan by restricting choices or changing prices (Bryan et al. (2010)). We discuss the implications of dynamic consistency on commitment demand in the context of our design in Section 4, where we discuss the results.

\subsection{The Consumption Allocation Experiment:}

The chocolate experiment that is the focus of this paper is conducted over three distinct days. In the first visit (Day 0), subjects are told that they are going to receive 6 pieces of chocolate in a week's time ${ }^{6}$. They will have two consecutive days over which to allocate consumption of these chocolates, which we call Day 1 and Day 2. Subjects are then asked to make an allocation plan of the chocolates over the two days. That is, they are asked to state, from the perspective of today, how many of their 6 chocolates they would ideally like to eat on the 1 st day, and how many on the 2nd day. Subjects are distributed decision sheets, on which they write their planned consumption for Day 1 and Day 2. Next, they are told that on Day 1, which is one week later, they will be free to consume their 6 chocolates over two days as they wish. That is, each subject will be able to state how much she would like to take at that point (on Day 1), and the remaining chocolates (if any) will be given to her on Day 2. ${ }^{7}$ Subjects are then introduced the commitment device, which is a "locked box". Chocolates that are placed in the locked box cannot be eaten before Day 2, even if one wishes so. Chocolates that are not locked can be eaten whenever one wishes ${ }^{8}$. In order to check understanding, children are asked comprehension questions, such as whether

\footnotetext{
${ }^{6}$ We use individually wrapped high-quality mini milk chocolates of a well-known brand.

${ }^{7}$ One could argue that chocolate is durable, that is, the children could take them all and keep them to consume at a later date. While this would be potentially plausible, we observe that almost all children eat the chocolates they get right then and there. We also do not observe many 6-0 choices for the two days' consumption allocation.

${ }^{8}$ While the commitment device does not have a monetary cost, it has a cost of restricting choices, as in, for example, Ashraf et al. (2006). Therefore, unless the student expects a self-control issue when the chocolates arrive, she should weakly prefer not to have any restrictions on her consumption set. In fact, if there is any uncertainty about future
} 
somebody that says "no" to the locked box has to eat all 6 chocolates on the 1st day, what the available consumption choices to somebody who locks a certain amount of chocolates are etc. ${ }^{9}$ After this, children are asked to state, again on a decision sheet, (1) whether they would like to put any chocolates in the locked box, (2) if so, how many they would like to put in the locked box. This concludes the first phase (Day 0) of the experiment. ${ }^{10}$

In order to elicit actual consumption levels, the classrooms are visited exactly one week after Day 0, on Day 1, with boxes that contain chocolate. The students are reminded of the procedures again, and they are asked to privately state how many out of their 6 chocolates they desire to eat now. All students are asked to state their current desired consumption, as if they were unconstrained and free to choose now. ${ }^{11}$ They are given this stated amount if they have enough unlocked chocolates, and any chocolates not consumed are left to the next day. That is, if the amount available is at least as large as the student's desired Day 1 consumption, then the student consumes the desired amount. If the number of unlocked chocolates is less than the student's Day 1 consumption, then the student gets only the chocolates available to her, and has to wait for the next day to get the rest. This concludes the second phase (Day 1) of the experiment. In the third and final phase (Day 2) of the experiment, students are just given their Day 2 allocation of chocolates, which will of course depend on how much they actually consumed in the previous day (Day 1). A summary of the experimental design is presented in Table 1.

<Table 1 here>

This design allows us to measure (1) planned consumption for two future dates, (2) the demand for commitment, (3) desired and actual consumption, and thereby identify both patience and timeinconsistency. One issue, however, is that the planned consumption allocation made on Day 0 is not "incentivized", and could potentially be subject to hypothetical bias. In order to assess whether this is a problem, we ran a subset of sessions with the above design, the only difference being that subjects were told that there was a 1 in 10 chance that they would be forced to stick to their plan on Day 1 , and we indeed implemented this. We do not find any differences in the planned allocations with or without

marginal utility, an exponential discounter should never choose to restrict her choices, i.e. never demand commitment.

${ }^{9}$ We actually used two boxes: a "locked box" and an "unlocked box" when presenting the rules to the children, in order to prevent children from viewing the use of the locked box as a novelty. Instructions are provided in the Appendix.

${ }^{10}$ The commitment device was introduced after the plan was made, that is, subjects made the allocation plan without knowledge of the commitment device. This design choice was made because knowing of the possibility of commitment could potentially lead children to view the planned allocation choice as less important or otherwise affect reports, for example by emphasizing the future.

${ }^{11}$ For subjects who placed chocolates in the locked box, this might be a biased measure, since they know that they cannot take chocolates out of the locked box and might have chosen to state amounts consistent with this. 
incentives (mean difference of 0.03 chocolates, $\mathrm{p}=0.38$ in a t-test), which gives us confidence to use the planned consumption allocations in our analyses.

\subsection{Multiple Price List and Convex Time Budget Discounting Experiments}

In addition to the consumption allocation experiment, we also have data on the same children's time preferences through a set of decisions that involve choices between smaller-earlier and larger-later rewards. A big portion of our data come from experiments that follow a "multiple price list" (MPL) format, where individuals make a series of choices between a fixed amount to be received today, and increasingly larger amounts to be received in the future. ${ }^{12}$ The minimum larger-later amount that induces the individual to be willing to wait is a measure of impatience. That is, more impatient individuals require a larger premium to be willing to sacrifice current consumption and wait for the future reward. In our experiments, we fix the earlier reward to be 2 gifts out of a gift box that contains toys, stationary, hair bands etc., whereas the larger rewards range between 2 and 10 gifts. We give subjects two multiple price list sheets that include 9 decisions each, between: (1) two gifts today versus more gifts to be received with a one week delay, (2) two gifts to be received in one week versus more gifts to be received in two weeks. ${ }^{13}$ At the end of the experiment, one decision out of one of the lists is randomly selected and rewards are given according to subjects' choices in the selected decision. By keeping the delay length the same and varying the delay to the earlier reward, these two sets of decisions allow us to both measure patience and identify time inconsistency.

For a smaller subset of our dataset, we use a Convex Time Budget (CTB) task (Andreoni and Sprenger (2012)) instead of an MPL task. In this task, individuals are asked to allocate 5 tokens between an earlier and a later option, where the later option involves interest. We vary the timing of the early reward and the delay consistently with the MPL task (today vs. one week later and one week vs. two weeks). For each of these time profiles, subjects make one decision with an interest rate of $r=0.25$ and one with $r=0.5$. In total, subjects make 4 decisions, one of which is selected randomly and implemented. ${ }^{14}$

\subsection{Questionnaires and Other Controls:}

We supplement our behavioral data with a set of questionnaires that elicit valuable information about the subjects' characteristics, family background and school outcomes. In particular, we have access to teacher surveys, whereby teachers answer several questions about each of their students, such as their success in

\footnotetext{
${ }^{12}$ See Andersen et al. (2006) for a methodological discussion.

${ }^{13}$ We took great care in explaining to the children that there would be no uncertainty in receiving their gifts, should they choose the delayed reward options.

${ }^{14}$ Available alternatives for each of the four choices are given in the Appendix. Fractional rewards are handled by having three types of gifts of different size: a "full gift", a "half gift", and a "quarter gift".
} 
school, how cognitively able the student is, and how wealthy their family is. In addition, we have questionnaires administered to students, which measure personality factors. In particular, we use a version of the "Early Adolescent Temperament Questionnaire" (Capaldi and Rothbart (1992), Ellis and Rothbart (2001)), that is designed to identify measures of inhibitory control, activation control, attention, frustration, surgency, fear, and aggression. ${ }^{15}$

\section{Results}

We have data from 2907 students from 101 classes in 41 elementary schools. The students are 3rdgraders, and the median age is 9 years. $51.8 \%$ of our sample is male. In the below analyses, we exclude 4 students who had chocolate allergies and did not complete the consumption part of the experiment, as well as 19 students with cognitive difficulties. ${ }^{16} 17$

\subsection{Planned Consumption:}

We first analyze planned consumption levels, which are elicited a week before the first period of actual consumption. An overwhelming majority (about 80\%) of the students state that they would like to eat half of their endowment on the 1st day and half on the 2nd day, suggesting a strong motive for consumption smoothing. The distribution of planned consumption on Day 1 is depicted in Figure 1, Panel A. Males' consumption plans are more heavily weighted toward the present, significant at the $5 \%$ level in a t-test $(\mathrm{p}=0.0098)$. Gender also remains significant in a set of OLS regressions that control for (1) the teacher's assessment of the child's success in school and the family's wealth, (2) temperament and personality factors that were obtained from the personality questionnaire (Table 2). ${ }^{18}$ In addition, children that are assessed to be highly successful by the teacher are found to make more patient plans, when personality factors are controlled for. Among the personality factors, inhibitory control, the ability to suppress urges, is positively correlated with a more patient plan. One concern here is that the

\footnotetext{
${ }^{15}$ The definitions of these temperament factors are given in the Appendix.

${ }^{16}$ These students are cognitively behind, and are part of a government program to incorporate them into the classrooms in order for them to benefit from potential positive peer effects.

${ }^{17} \mathrm{We}$ also collected information about how much the children like chocolate. We use the full data in the following analyses, but the results are robust to excluding the small fraction of subjects $(12.5 \%)$ who state they "do not like chocolate much".

${ }^{18}$ In all the regressions reported in the paper, heteroskedasticity-robust standard errors are used. In this and other regressions where we use control variables coming from the student surveys and teacher assessment variables, such as school success, we lose some observations. The reason for this is that some of the surveys had to be done in the last week of classes, which saw a significant number of students leave for vacation. This attrition is usual (and likely to be random) since many Turkish families tend to go to their villages or summer homes for extended periods in the summer. We in fact ran a set of regressions on the probability of being present for the second visit. None of our behavioral measures are significantly correlated with the attrition. In addition, all the results in the $1^{\text {st }}$ (main) column of the regression tables are robust when we restrict attention to the (smaller) sample that has all correlates available.
} 
predominance of equal splits could prevent us from assessing the correlates of consumption plans with statistical precision. If we exclude the equal planned allocations, we find that (1) the relationships reported in Table 2 are robust, (2) some of the results that do not reach statistical significance, such as the correlation of high success with patience in Column 2, become significant.

$<$ Table 2 here>

\subsection{The Demand for Commitment:}

$68.5 \%$ of our subjects say "yes" to the commitment device and put, on average, 3.46 chocolates into the locked box, conditional on putting a positive amount. Figure 1, Panel B shows the distribution of the amount locked for Day 2. We first analyze the determinants of commitment device take-up. Table 3 shows that students whose plans indicate a higher consumption on Day 1 are less likely to demand commitment. That is, students who would like to consume higher amounts on Day 2 are more likely to put chocolates in the locked box. In terms of marginal effects, this amounts to a 6 percentage point increase in the probability of commitment take-up for each additional chocolate allocated to Day 2. This provides our first piece of evidence that there is a positive relationship between patience and the demand for commitment. Column 2 of Table 3 shows that high family wealth increases the propensity to demand commitment whereas children that are more successful in school are less likely to demand commitment. This could be because successful students trust themselves to stick to their consumption plans. We return to this issue in the discussion of present bias in Section 3.4. When we add personality controls, children that score high on surgency and fear and those who score low on aggression are more likely to commit.

<Table 3 here>

We then turn to the determinants of the locked amount, conditional on demanding commitment. As expected, the planned allocation for Day 2 has a significantly positive effect on the amount locked (Table 4). While there was no gender difference in the propensity to demand commitment, boys that demand commitment lock a significantly higher amount than girls, controlling for their Day 2 plan. Successful students that chose to commit tend to lock a significantly lower amount, consistently with the result that they demand less commitment in the first place, whereas none of the personality factors are significant.

<Table 4 here>

\subsection{Discounting, Time Inconsistency and the Demand for Commitment}

A unique aspect of our dataset is that it is possible to explore patience and time inconsistency across different discounting tasks, within person. We start by defining patience and time inconsistency in the 
multiple price list (MPL) task. We quantify patience in the MPL task by how many "early" decisions the subject made, in the decision list that presents trade-offs between rewards coming today and 1 week later. For measuring dynamic consistency, we compare choices made between today and one week later, with the ones made between one week and two weeks later. In this task, a standard exponential discounter would be expected to choose the same switch-point in the two lists that involve the same delay of one week. That is, the required premium to wait for the same larger reward would only depend on the length of delay, and not when the sooner reward comes. Such behavior indicates dynamic consistency. We classify our subjects as "increasingly patient" (or "hyperbolic", in line with the literature) if the premium they require to wait is higher when choosing between today and 1 week later, than when choosing between 1 week and 2 weeks later. Such individuals are more patient in future trade-offs that do not involve the present. In contrast, we classify subjects as "increasingly impatient" (or "hypobolic") if they are more patient in decisions that contain trade-offs between today and 1 week, than in decisions between 1 week and 2 weeks. ${ }^{19}$ The latter two types of choices would imply time-inconsistency, whereby students should wish to change their 1 week later-2 weeks later decisions, if offered a chance to change when one week later becomes "today". Although the MPL methodology does not test this implication directly, our consumption experiment does offer a measure of planned vs. actual consumption. Examining the relationship between consumption plans, the demand for commitment, and present bias in the consumption task and patience/time inconsistency in the MPL discounting task within person can therefore provide richer insights into the preferences of the subjects.

We first look at the relationship between patience as measured by the MPL task and planned consumption choices in the chocolate task, and find that indeed, there is a significant positive relationship between the number of early choices in the time task and the planned consumption amount in Day 1 (Table 5, Column 1). ${ }^{20}$ That is, subjects who behave more patiently in the MPL task also make more patient plans over the consumption good. More patient subjects are also more likely to demand the commitment device, as the coefficient of the number of impatient choices is significantly negative in a regression of the commitment device take-up. ${ }^{21}$ (Table 5, Column 2) When we add the time consistency variables into our regression of commitment device take-up, we find that subjects who are identified as "increasingly impatient" (hypobolic) are significantly less likely to demand commitment than hyperbolic and exponential discounters (Table 5, Column 3). While we do not find a significant difference between hyperbolic and

\footnotetext{
${ }^{19}$ We use the terms "hyperbolic" and "increasingly patient" as well as "hypobolic" and "increasingly impatient" interchangeably in the paper, but do not make a claim that the preferences we identify necessarily fit these functional forms.

${ }^{20}$ We lose some observations here because some subjects did not understand the MPL task and/or made inconsistent choices that involved switching between the two columns more than once.

${ }^{21}$ The significance of MPL impatience in fact remains even when we control for subjects' consumption plan, which is by itself a measure of patience. Results of regressions that include controls for the plan are available upon request.
} 
exponential discounters, the sign of the hyperbolic dummy is positive, which is consistent with the theoretical prediction. If we consider the amount committed for the whole sample, we find that hypobolics and the more patient lock significantly fewer chocolates (Table 5, Column 4). Within the group that has taken up commitment, patience (as measured by the MPL) itself does not have an effect, but hypobolics again lock significantly fewer chocolates (Table 5, Column 5). ${ }^{22}$

As mentioned before, for a smaller subset of our dataset, we have data from a Convex Time Budget (CTB) task, where children allocate tokens between an earlier option that pays no interest, and a later option that pays interest. This allocation is done four times: for "now vs. one week later" with $\mathrm{r}=0.25$ and $\mathrm{r}=0.5$, and for "one week vs. two weeks later" with $\mathrm{r}=0.25$ and $\mathrm{r}=0.5$. Since both the MPL and the CTB task involve now vs. one week and one week vs. two weeks choices, it is possible to categorize subjects into "hyperbolic", "exponential" and "hypobolic" discounters in the pooled data. In the CTB task, we define subjects who wanted the same number of gifts on the earlier date, regardless of when the earlier date comes, as time consistent. Subjects who want more gifts on the earlier date when the earlier date is today are classified as hyperbolic, and subjects who want more rewards on the earlier date when the earlier date is a week from now are classified as hypobolic. ${ }^{23}$ While choices in the MPL and CTB tasks are not directly comparable, it is possible to construct a "patience dummy" from the pooled data, which takes the value of 1 for children who have made more patient choices than the median choice in the relevant task. When we use these patience and time inconsistency variables with the pooled data, we again obtain the results that (1) patient children make more patient consumption plans, (2) patient children are more likely to demand the commitment device, (3) hypobolic discounters are less likely to demand the commitment device, (4) hypobolic discounters lock less, conditional on demanding commitment (see Appendix, Table 5B).

$<$ Table 5 here>

\subsection{Actual Consumption Choices}

Our measurement methodology allows us to observe subjects' actual and desired consumption choices as well. However, since all children self-select into or out of the commitment device, analyses can only be done on selected samples.

\footnotetext{
${ }^{22}$ The results remain if we use the difference between the numbers of impatient choices in the "today vs. one week" set of the MPL and the "one week vs. two weeks" set, in order to capture the degree of "increasing patience" or "present bias" in the MPL task continuously. In unreported regressions of both the propensity to lock and the locked amount, the coefficient of the variable that reflects additional impatient choices today is positive and significant at the $1 \%$ level (these results are available upon request).

${ }^{23}$ In our classifications, we drop subjects who make inconsistent choices, in the sense of behaving like a hyperbolic with one interest rate and behaving like a hypobolic with another.
} 
In order to analyze self-control, we focus on desired consumption versus the initial plan that the student had made, and define "present bias" to be the desired minus planned consumption for Day 1 . The desired consumption information is gathered from all subjects, regardless of whether they took up the commitment device or not. That is, all subjects are asked to express how much they would have wished to consume, had they been free to decide at that point. A paired t-test shows that this present bias measure is significantly positive in the full sample $(\mathrm{p}=0.004)$. That is, when Day 1 comes, children on average wish to eat more than what they had planned for.

Since the children who took the commitment device know that they have only so many chocolates to consume on the 1st day and may not want to express a higher amount than that, our present bias measure for these children is prone to hypothetical bias. We therefore focus on the children who did not demand commitment and therefore are free to choose, as the present bias measure is fully incentivized in this case, and these children are faced with a true self-control task. We find that these children also demand more chocolates than they had planned for on the first day $(\mathrm{p}=0.000)$, confirming the prevalence of present bias on average. $64.4 \%$ of the children stick to their plan, whereas $21.9 \%$ end up consuming more than planned (see Figure 1, Panel C for the distribution).

Table 6 reports a set of regression results on the determinants of the propensity to display positive present bias in this sample. We find that children who are highly successful at school are less likely to desire and eat more than their plan (Table 6, columns 1 and 2). In terms of marginal effects, successful students are 10 percentage points less likely to exhibit a self-control problem. Among personality variables, we find that activation control, which is defined as the ability to perform an undesired action, is negatively correlated with present bias incidence (Table 6, Column 3).

Another important question is whether lack of self-control in actual chocolate consumption has any relationship with time inconsistency in the MPL task. Table 6, Column 4 uses the number of additional impatient choices made in the "today vs. one week" sheet of the MPL, as compared to the "one week vs. two weeks" sheet, in order to capture the degree of present bias or "increasing patience" in the MPL task. The incidence of self-control issues in the chocolate task is significantly higher for children that make more present-biased choices in the MPL task. Notice that this result pertains to the sample of children who did not take the commitment device, and therefore is consistent with naïve choices by hyperbolic discounters.

$<$ Table 6 here> 


\section{Discussion and Concluding Remarks}

While recent research has accumulated evidence on time preferences in children, how children respond to an opportunity to self-restrict choices is an open research question of policy relevance. The issue of whether sophistication exists at a young age, and what factors predict its prevalence might have implications for educational efforts to encourage savings behavior as well as to curb impulsive consumption. Given the promise of early educational interventions in improving non-cognitive skills, designing classroom education to improve self-control may be possible through identifying sophistication and exploring the role of commitment devices to cope with self-control problems. The obvious first step toward achieving this goal is to pin down the nature of these problems and establish their relationship with other individual characteristics. The current paper takes on this mission and provides initial evidence to establish a knowledge-base to inform policy discussions.

We find a considerable demand for commitment among our sample of children. Students that do not take up the commitment device are found to display present bias in their actual consumption choices. Our results highlight several factors as correlates in commitment choice: children who are more patient are more likely to take the commitment device. The demand for commitment is also higher among students with high socioeconomic status, whereas students who are more successful in school are less likely to commit. A speculative explanation here could be that these correlations reflect exposure and learning about own self-control behavior. Successful students may know, from their studying routine, that they are able to control their consumption urges, whereas children from wealthy families may have faced situations with temptation more frequently, and may have become more sophisticated about their own self-control issues. Further research should explore the mechanisms behind these finding.

One of the most striking results that emerge from the data is the existence of a "patience" trait that seems to be stable within-person and reflected in experimental behavior as well as actual life outcomes. Individuals who are patient in the multiple price list and/or convex time budget elicitation tasks also make more patient consumption plans in chocolate consumption. Within-person stability of attitudes both across time and across elicitation tasks has been a recent area of interest in economics. Our data gives an optimistic answer to the question of whether individual-level preferences are correlated across tasks, at least in the context of time preference and in a sample of children. In addition, we find that some personality measures such as inhibitory control and activation control correlate with our behavioral 
measures, suggesting a close connection between non-cognitive traits and economic preferences that can also be important to know for the question of malleability of attitudes and behavior in children.

In our data, we document a significant number of choices that are "increasingly impatient". There is in fact a recently growing body of work on increasing impatience (sometimes called hypobolic preferences or "reverse time inconsistency"). Some studies have provided a theoretical framework for accommodating such preferences (e.g. Bleichrodt et al. (2009)), and several studies have presented evidence for this type of behavior with different experimental designs (Dohmen et al. (2012), Eil (2012), Sayman and Onculer (2009)). It is interesting to consider what this type of preference implies for the demand for commitment. In the well-studied case of increasing patience (consistent with hyperbolic discounting), the sophisticated demands the commitment device because they are aware that they will not be able to stick to their consumption plans. The naïve, on the other hand, are expected not to commit. In contrast, the increasingly impatient (consistent with hypobolic discounting), if sophisticated, would know that when the time comes, they would be willing to wait for the next day. Therefore, a sophisticated hypobolic does not have reason to demand commitment, which is consistent with what we find. In our data, hypobolics are less likely than other types to opt into commitment, and if they do, they use the commitment device less intensively. On the other hand, the existence of present bias in the unconstrained sample, and its positive association with the degree of "increasing patience" suggests that at least some of the hyperbolic students who do not take commitment could be naïve about their self-control problems. Our data also reveal important relationships between decision-making over time and the actual school success of children. Controlling for the plan, high academic success leads to a lower amount committed. In addition, highly successful students are less likely to exhibit a self-control problem on the actual day of consumption. Identifying these relationships contributes to the recent literature that has studied behavior in experiments in relation to real-life choices and outcomes. In addition, the results may have implications as to which types of students can be targeted for educational policies that aim to improve self-control.

Since in our design the present bias measure is properly incentivized only for students who did not demand commitment, it is difficult to analyze the relationship between time preference and present bias in a way that is free of self-selection. Further research should explore this relationship further by implementing "probabilistic commitment", i.e. by having the committed choices not bind, randomly. 


\section{References:}

Andersen, S., Harrison, G. W., Lau, M. I., \& Rutström, E. E. ,2006. Elicitation using multiple price list formats. Experimental Economics, 9(4), 383-405.

Andreoni, J., Sprenger, C., 2012. Estimating Time Preferences from Convex Budgets. American Economic Review 102 (7), 3333-56.

Ashraf, N., Karlan, D., Yin, W., 2006. Tying Odysseus to the mast: Evidence from a commitment savings product in the Philippines. The Quarterly Journal of Economics 121 (2), 635-672.

Becker, A., Deckers, T., Dohmen, T., Falk, A., Kosse, F., 2012. The relationship between economic preferences and psychological personality measures. Annual Review of Economics 4, 453-478.

Bettinger, E., Slonim, R., 2007. Patience among children. Journal of Public Economics 91 (1), 343-363.

Bickel, W., Odum, A., Madden, G., 1999. Impulsivity and Cigarette Smoking: delay discounting in current, never and exsmokers. Psychopharmacology 146 (4), 447-454.

Blanco, M., Engelmann, D. and Normann, H.T., 2011. A within-subject analysis of other-regarding preferences. Games and Economic Behavior 72(2), 321-338.

Bleichrodt, H., Rohde, K. I., Wakker, P. P., 2009. Non-hyperbolic time inconsistency. Games and Economic Behavior 66 (1), 27-38.

Borghans, L., Duckworth, A., Heckman, J.J., Ter Weel, B., 2008. The economics and psychology of personality traits. Journal of Human Resources 43 (4), 972-1059.

Bryan, G., Karlan, D., Nelson, S., 2010. Commitment devices. Annual Review of Economics 2 (1), 671698.

Bucciol, A., Houser, D., Piovesan, M., 2011. Temptation and productivity: A field experiment with children. Journal of Economic Behavior \& Organization 78 (1), 126-136.

Burks, S., Carpenter, J., Götte, L., Rustichini, A., 2012. Which measures of time preference best predict outcomes: Evidence from a large-scale field experiment. Journal of Economic Behavior and Organization 84 (1), 308-320.

Capaldi, D. M., Rothbart, M. K., 1992. Development and validation of an early adolescent temperament measure. Journal of Early Adolescence 12 (2), 153-173.

Carneiro, P., Heckman, J., 2003. Human capital policy (No. w9495). National Bureau of Economic Research.

Castillo, M., Ferraro, P. J., Jordan, J. L., Petrie, R., 2011. The today and tomorrow of kids: Time preferences and educational outcomes of children. Journal of Public Economics 95 (11), 1377-1385.

Cunha, F., Heckman, J. J., Schennach, S. M., 2010. Estimating the technology of cognitive and noncognitive skill formation. Econometrica 78 (3), 883-931. 
DellaVigna, S., Paserman, D., 2005. Job Search and Impatience. Journal of Labor Economics 23 (3), $527-$ 588.

DellaVigna, S., 2009. Psychology and Economics: Evidence from the Field. Journal of Economic Literature, 47(2), 315-372.

Dohmen, T. J., Falk, A., Huffman, D., Sunde, U., 2012. Interpreting Time Horizon Effects in InterTemporal Choice. IZA Discussion Paper No. 6385.

Eil, D., 2012. Hypobolic Discounting and the Willingness to Wait. George Mason University Working Paper in Economics No. 12-28.

Ellis, L. K., Rothbart, M. K., 2001. Revision of the Early Adolescent Temperament Questionnaire. Poster presented at the biennial meeting of the Society for Research in Child Development, Minneapolis, MN.

Finke, M.S., Huston, S.J, 2013. Time preference and the importance of saving for retirement. Journal of Economic Behavior and Organization 89, 23-34.

Fuchs, V. R., 1982. Time Preferences and Health: An Exploratory Study. Economic Aspects of Health, 93-120.

Golsteyn, B. H., Grönqvist, H., Lindahl, L., 2013. Adolescent Time Preferences Predict Lifetime Outcomes. The Economic Journal.

Heckman, J. J., Rubinstein, Y., 2001. The importance of noncognitive skills: Lessons from the GED testing program. The American Economic Review 91 (2), 145-149.

Heckman, J., Stixrud, J., Urzua, S., 2006. The Effects of Cognitive and Noncognitive Abilities on Labor and Social Behavior. Journal of Labor Economics 24 (3), 411-482.

Jamison, J., Karlan, D., \& Zinman, J., 2012. Measuring risk and time preferences and their connections with behavior. Unpublished Manuscript.

Knudsen, E. I., Heckman, J. J., Cameron, J., Shonkoff J. P., 2006. Economic, neurobiological, and behavioral perspectives on building America's future workforce. Proceedings of the National Academy of Sciences 103 (27), 10155-10162.

Laibson, D., 1997. Golden Eggs and Hyperbolic Discounting. Quarterly Journal of Economics 112 (2), 443-77.

Laibson, D. I., Repetto, A., Tobacman, J., Hall, R. E., Gale, W. G., Akerlof, G. A., 1998. Self-control and saving for retirement. Brookings Papers on Economic Activity, 91-196.

Meier, S., Spenger, C., 2010. Present-Biased Preferences and Credit Card Borrowing. AEJ: Applied Economics 2, 193-210.

Moffitt, T. E., Arseneault, L., Belsky, D., Dickson, N., Hancox, R.J., Harrington, H., Houts, R., Poulton, R.,Roberts, B. W., Ross, S., Sears, N. R., Thomsom, W. M., Caspi, A., 2011. A gradient of childhood 
self-control predicts health, wealth, and public safety. Proceedings of the National Academy of Sciences 108 (7), 2693-98.

O’Donoghue, T., Rabin, M., 2001. Choice and Procrastination. Quarterly Journal of Economics, 116(1), 121-160.

Sayman, S., Öncüler, A., 2009. An investigation of time inconsistency. Management Science 55 (3), 470482.

Sutter, M., Kocher, M.G., Ruetzler, D., Trautmann, S.T., 2013. Impatience and uncertainty: Experimental decisions predict adolescents' field behavior. American Economic Review 103 (1), 510-531.

TABLES:

Table 1: Summary of the Experimental Design

\begin{tabular}{|c|c|c|}
\hline Day 0 (now) & Day 1 (one week later) & Day 2 (one week+one day) \\
\hline $\begin{array}{l}\text { - Consumption plan for } \\
\text { Day } 1 \text { and Day } 2 \\
\text { - Commitment Take-up: } \\
\text { YES or NO } \\
\text { - Amount Committed (if YES) }\end{array}$ & $\begin{array}{l}\text { - State Desired Consumption } \\
\text { (Wish) } \\
\text { - \# of Available Chocolates: } 6 \\
\text { if NO to commitment, } \\
\text { Unlocked Amount if YES to } \\
\text { commitment } \\
\text { - Day } 1 \text { Consumption Realized } \\
\text { According to Desired } \\
\text { Consumption and \# of } \\
\text { Available Chocolates }\end{array}$ & $\begin{array}{l}\text { - Any chocolates } \\
\text { consumed on Day } 1 \text { are } \\
\text { consumed }\end{array}$ \\
\hline
\end{tabular}


Table 2: Determinants of the Allocation Plan

\begin{tabular}{|c|c|c|c|}
\hline & $\begin{array}{l}(1) \\
\# \text { of chocolates } \\
\text { planned for Day1 }\end{array}$ & $\begin{array}{l}\text { (2) } \\
\# \text { of chocolates } \\
\text { planned for Day } 1\end{array}$ & $\begin{array}{l}\text { (3) } \\
\# \text { of chocolates } \\
\text { planned for Day1 }\end{array}$ \\
\hline Male & $\begin{array}{l}0.0768 * * * \\
(0.0295)\end{array}$ & $\begin{array}{l}0.0839 * * \\
(0.0349)\end{array}$ & $\begin{array}{l}0.0851 * * \\
(0.0382)\end{array}$ \\
\hline High success & & $\begin{array}{l}-0.0400 \\
(0.0360)\end{array}$ & $\begin{array}{l}-0.0742 * \\
(0.0406)\end{array}$ \\
\hline High wealth & & $\begin{array}{l}0.0140 \\
(0.0445)\end{array}$ & $\begin{array}{l}0.0102 \\
(0.0495)\end{array}$ \\
\hline Inhibitory Control & & & $\begin{array}{l}-0.0845^{* * *} \\
(0.0350)\end{array}$ \\
\hline Surgency & & & $\begin{array}{l}-0.0151 \\
(0.0282)\end{array}$ \\
\hline Fear & & & $\begin{array}{l}-0.0234 \\
(0.0260)\end{array}$ \\
\hline Attention & & & $\begin{array}{l}-0.00191 \\
(0.0363)\end{array}$ \\
\hline Aggression & & & $\begin{array}{l}0.000867 \\
(0.0426)\end{array}$ \\
\hline Activation Control & & & $\begin{array}{l}0.0105 \\
(0.0351)\end{array}$ \\
\hline Grit & & & $\begin{array}{l}0.0353 \\
(0.0376)\end{array}$ \\
\hline Frustration & & & $\begin{array}{l}0.0363 \\
(0.0270)\end{array}$ \\
\hline Constant & $\begin{array}{l}2.909 * * * \\
(0.0192)\end{array}$ & $\begin{array}{l}2.913 * * * \\
(0.0308)\end{array}$ & $\begin{array}{l}3.096 * * * * \\
(0.231)\end{array}$ \\
\hline $\begin{array}{l}\text { Observations } \\
\mathrm{R}^{2}\end{array}$ & 2,907 & 2,056 & 1,606 \\
\hline
\end{tabular}


Table 3: Commitment Device Take-Up

\begin{tabular}{|c|c|c|c|}
\hline & $\begin{array}{l}\text { (1) } \\
\text { Commitment } \\
\text { Take-up }\end{array}$ & $\begin{array}{l}\text { (2) } \\
\text { Commitment } \\
\text { Take-up }\end{array}$ & $\begin{array}{l}\text { (3) } \\
\text { Commitment } \\
\text { Take-up }\end{array}$ \\
\hline Plan for Day1 & $\begin{array}{l}-0.266 * * * \\
(0.0545)\end{array}$ & $\begin{array}{l}-0.256 * * * \\
(0.0673)\end{array}$ & $\begin{array}{l}-0.239 * * * \\
(0.0774)\end{array}$ \\
\hline Male & $\begin{array}{l}-0.0524 \\
(0.0804)\end{array}$ & $\begin{array}{l}-0.133 \\
(0.0977)\end{array}$ & $\begin{array}{l}-0.126 \\
(0.117)\end{array}$ \\
\hline High success & & $\begin{array}{l}-0.193 * \\
(0.0997)\end{array}$ & $\begin{array}{l}-0.134 \\
(0.118)\end{array}$ \\
\hline High wealth & & $\begin{array}{l}0.252 * * \\
(0.123)\end{array}$ & $\begin{array}{l}0.233 * \\
(0.136)\end{array}$ \\
\hline Inhibitory control & & & $\begin{array}{l}0.0431 \\
(0.102)\end{array}$ \\
\hline Surgency & & & $\begin{array}{l}0.169 * * \\
(0.0761)\end{array}$ \\
\hline Fear & & & $\begin{array}{l}0.135^{*} \\
(0.0701)\end{array}$ \\
\hline Aggression & & & $\begin{array}{l}-0.219 * \\
(0.120)\end{array}$ \\
\hline Attention & & & $\begin{array}{l}0.00403 \\
(0.0980)\end{array}$ \\
\hline Activation control & & & $\begin{array}{l}-0.105 \\
(0.103)\end{array}$ \\
\hline Grit & & & $\begin{array}{l}-0.139 \\
(0.109)\end{array}$ \\
\hline Frustration & & & $\begin{array}{l}-0.0327 \\
(0.0741)\end{array}$ \\
\hline Constant & $\begin{array}{l}1.596 * * * \\
(0.173)\end{array}$ & $\begin{array}{l}1.739 * * * \\
(0.221)\end{array}$ & $\begin{array}{l}1.658 * * \\
(0.744)\end{array}$ \\
\hline Observations & 2,907 & 2,056 & 1,606 \\
\hline
\end{tabular}

Note: The dependent variable "Commitment Take-up " is a dummy variable that takes the value of 1 if the child chooses to lock some of his/her chocolates and zero otherwise. Robust standard errors in parentheses. ${ }^{* * *} \mathrm{p}<0.01,{ }^{* *} \mathrm{p}<0.05,{ }^{*} \mathrm{p}<0.1$ 
Table 4: Amount Committed, Conditional on Commitment

\begin{tabular}{|c|c|c|c|}
\hline & $\begin{array}{l}1) \\
\text { Amount locked }\end{array}$ & $\begin{array}{l}(2) \\
\text { Amount locked }\end{array}$ & $\begin{array}{l}3) \\
\text { Amount locked }\end{array}$ \\
\hline Plan for Day 2 & $\begin{array}{l}0.392 * * * \\
(0.0510)\end{array}$ & $\begin{array}{l}0.387 * * * \\
(0.0579)\end{array}$ & $\begin{array}{l}0.356 * * * \\
(0.0649)\end{array}$ \\
\hline Male & $\begin{array}{l}0.158 * * * \\
(0.0499)\end{array}$ & $\begin{array}{l}0.184 * * * \\
(0.0592)\end{array}$ & $\begin{array}{l}0.186 * * * \\
(0.0679)\end{array}$ \\
\hline High success & & $\begin{array}{l}-0.191 * * * \\
(0.0600)\end{array}$ & $\begin{array}{l}-0.148 * * \\
(0.0681)\end{array}$ \\
\hline High wealth & & $\begin{array}{l}-0.0589 \\
(0.0708)\end{array}$ & $\begin{array}{l}-0.0396 \\
(0.0786)\end{array}$ \\
\hline Inhibitory control & & & $\begin{array}{l}0.00233 \\
(0.0610)\end{array}$ \\
\hline Aggression & & & $\begin{array}{l}0.0994 \\
(0.0732)\end{array}$ \\
\hline Surgency & & & $\begin{array}{l}0.0186 \\
(0.0454)\end{array}$ \\
\hline Fear & & & $\begin{array}{l}0.00183 \\
(0.0420)\end{array}$ \\
\hline Attention & & & $\begin{array}{l}0.0547 \\
(0.0580)\end{array}$ \\
\hline Activation control & & & $\begin{array}{l}-0.0744 \\
(0.0592)\end{array}$ \\
\hline Grit & & & $\begin{array}{l}-0.0471 \\
(0.0655)\end{array}$ \\
\hline Frustration & & & $\begin{array}{l}0.0109 \\
(0.0449)\end{array}$ \\
\hline Constant & $\begin{array}{l}2.162 * * * \\
(0.161)\end{array}$ & $\begin{array}{l}2.297 * * * \\
(0.188)\end{array}$ & $\begin{array}{l}2.446 * * * \\
(0.500)\end{array}$ \\
\hline $\begin{array}{l}\text { Observations } \\
\mathrm{R}^{2}\end{array}$ & $\begin{array}{l}1,980 \\
0.066\end{array}$ & $\begin{array}{l}1,438 \\
0.072\end{array}$ & $\begin{array}{l}1,129 \\
0.070\end{array}$ \\
\hline
\end{tabular}

Note: The dependent variable "Amount locked" is the number of chocolates the child chooses to lock, conditional on having demanded the commitment device. Robust standard errors in parentheses, $* * * \mathrm{p}<0.01, * * \mathrm{p}<0.05, * \mathrm{p}<0.1$ 
Table 5: Relationship with Patience and Time Inconsistency

\begin{tabular}{|c|c|c|c|c|c|}
\hline & $\begin{array}{l}\text { (1) } \\
\text { \# of chocolates } \\
\text { planned for } \\
\text { Day1 }\end{array}$ & $\begin{array}{l}\text { (2) } \\
\text { Commitment } \\
\text { Take-up }\end{array}$ & $\begin{array}{l}\text { (3) } \\
\text { Commitment } \\
\text { Take-up }\end{array}$ & $\begin{array}{l}\text { (4) } \\
\text { Amount locked } \\
\text { (all) }\end{array}$ & $\begin{array}{l}\text { (5) } \\
\text { Amount locked } \\
\text { (conditional) }\end{array}$ \\
\hline $\begin{array}{l}\text { \# of early choices in } \\
\text { MPL }\end{array}$ & $\begin{array}{l}0.0134 * \\
(0.00719)\end{array}$ & $\begin{array}{l}-0.0634 * * * \\
(0.0187)\end{array}$ & $\begin{array}{l}-0.0724 * * * \\
(0.0199)\end{array}$ & $\begin{array}{l}-0.0685 * * * \\
(0.0179)\end{array}$ & $\begin{array}{l}-0.0225 \\
(0.0144)\end{array}$ \\
\hline Hyperbolic & & & $\begin{array}{l}0.115 \\
(0.159)\end{array}$ & $\begin{array}{l}0.157 \\
(0.133)\end{array}$ & $\begin{array}{l}0.107 \\
(0.101)\end{array}$ \\
\hline Hypobolic & & & $\begin{array}{l}-0.256^{* *} \\
(0.115)\end{array}$ & $\begin{array}{l}-0.313 * * * \\
(0.0946)\end{array}$ & $\begin{array}{l}-0.181 * * * \\
(0.0669)\end{array}$ \\
\hline Male & $\begin{array}{l}0.0436 \\
(0.0322)\end{array}$ & $\begin{array}{l}-0.0702 \\
(0.0982)\end{array}$ & $\begin{array}{l}-0.0656 \\
(0.0983)\end{array}$ & $\begin{array}{l}0.0443 \\
(0.0805)\end{array}$ & $\begin{array}{l}0.114^{*} \\
(0.0588)\end{array}$ \\
\hline Constant & $\begin{array}{l}2.885 * * * \\
(0.0280)\end{array}$ & $\begin{array}{l}1.148 * * * \\
(0.0874)\end{array}$ & $\begin{array}{l}1.216 * * * \\
(0.0945)\end{array}$ & $\begin{array}{l}2.719 * * * \\
(0.0748)\end{array}$ & $\begin{array}{l}3.520 * * * \\
(0.0548)\end{array}$ \\
\hline $\begin{array}{l}\text { Observations } \\
\mathrm{R}^{2}\end{array}$ & $\begin{array}{l}2,082 \\
0.003\end{array}$ & 2,082 & 2,082 & $\begin{array}{l}2,076 \\
0.013\end{array}$ & $\begin{array}{l}1,495 \\
0.010\end{array}$ \\
\hline
\end{tabular}

Note: The dependent variable "commitment take-up" is a dummy variable that takes the value of 1 if the child chooses to lock some of his/her chocolates and zero otherwise. The dependent variable "amount locked (all)" is the number of chocolates the child chooses to lock, and takes the value zero if the child chooses not to lock his/her chocolates. "Amount locked (conditional)" is the number of chocolates the child chooses to lock conditional on take-up. Columns 1, 4 and 5 report OLS regressions. Columns 2 and 3 report logit regressions. Robust standard errors in parentheses. $* * * \mathrm{p}<0.01, * * \mathrm{p}<0.05, * \mathrm{p}<0.1$ 
Table 6: Determinants of Present Bias Incidence with No Commitment

\begin{tabular}{|c|c|c|c|c|}
\hline & $\begin{array}{l}\text { (1) } \\
\text { PB incidence } \\
\text { (unconstrained) }\end{array}$ & $\begin{array}{l}\text { (2) } \\
\text { PB incidence } \\
\text { (unconstrained) }\end{array}$ & $\begin{array}{l}\text { (3) } \\
\text { PB incidence } \\
\text { (unconstrained) }\end{array}$ & $\begin{array}{l}\text { (4) } \\
\text { PB incidence } \\
\text { (unconstrained) }\end{array}$ \\
\hline Male & $\begin{array}{l}0.299 \\
(0.183)\end{array}$ & $\begin{array}{l}-0.00657 \\
(0.229)\end{array}$ & $\begin{array}{l}-0.0177 \\
(0.249)\end{array}$ & $\begin{array}{l}0.111 \\
(0.235)\end{array}$ \\
\hline High success & & $\begin{array}{l}-0.616^{* * *} \\
(0.229)\end{array}$ & $\begin{array}{l}-0.657 * * \\
(0.262)\end{array}$ & \\
\hline High wealth & & $\begin{array}{l}-0.129 \\
(0.293)\end{array}$ & $\begin{array}{l}-0.176 \\
(0.320)\end{array}$ & \\
\hline $\begin{array}{l}\text { \# of early choices in } \\
\text { MPL }\end{array}$ & & & & $\begin{array}{l}-0.00330 \\
(0.0423)\end{array}$ \\
\hline $\begin{array}{l}\text { Degree of present } \\
\text { bias in MPL }\end{array}$ & & & & $\begin{array}{l}0.146 * * \\
(0.0598)\end{array}$ \\
\hline Inhibitory control & & & $\begin{array}{l}-0.200 \\
(0.226)\end{array}$ & \\
\hline Aggression & & & $\begin{array}{l}-0.279 \\
(0.264)\end{array}$ & \\
\hline Surgency & & & $\begin{array}{l}-0.00699 \\
(0.163)\end{array}$ & \\
\hline Fear & & & $\begin{array}{l}-0.160 \\
(0.143)\end{array}$ & \\
\hline Attention & & & $\begin{array}{l}0.0133 \\
(0.211)\end{array}$ & \\
\hline Activation control & & & $\begin{array}{l}-0.365^{*} \\
(0.216)\end{array}$ & \\
\hline Grit & & & $\begin{array}{l}0.161 \\
(0.206)\end{array}$ & \\
\hline Frustration & & & $\begin{array}{l}0.0443 \\
(0.157)\end{array}$ & \\
\hline Constant & $\begin{array}{l}-1.440 * * * \\
(0.139)\end{array}$ & $\begin{array}{l}-1.025^{* * *} \\
(0.198)\end{array}$ & $\begin{array}{l}1.185 \\
(1.376)\end{array}$ & $\begin{array}{l}-1.238^{* * * *} \\
(0.214)\end{array}$ \\
\hline Observations & 722 & 479 & 422 & 426 \\
\hline
\end{tabular}

Note: "PB incidence" is a dummy variable that takes the value of 1 if the student is present biased, and 0 otherwise. Degree of present bias in MPL is captured by the number of additional early choices in the today-one week sheet of the MPL task. The sample only includes subjects that were unconstrained by the commitment device. The results reported are from logit regressions. Robust standard errors in parentheses. $* * * \mathrm{p}<0.01, * * \mathrm{p}<0.05, * \mathrm{p}<0.1$ 
Figure 1: Planned Consumption, Commitment Demand, and Present Bias
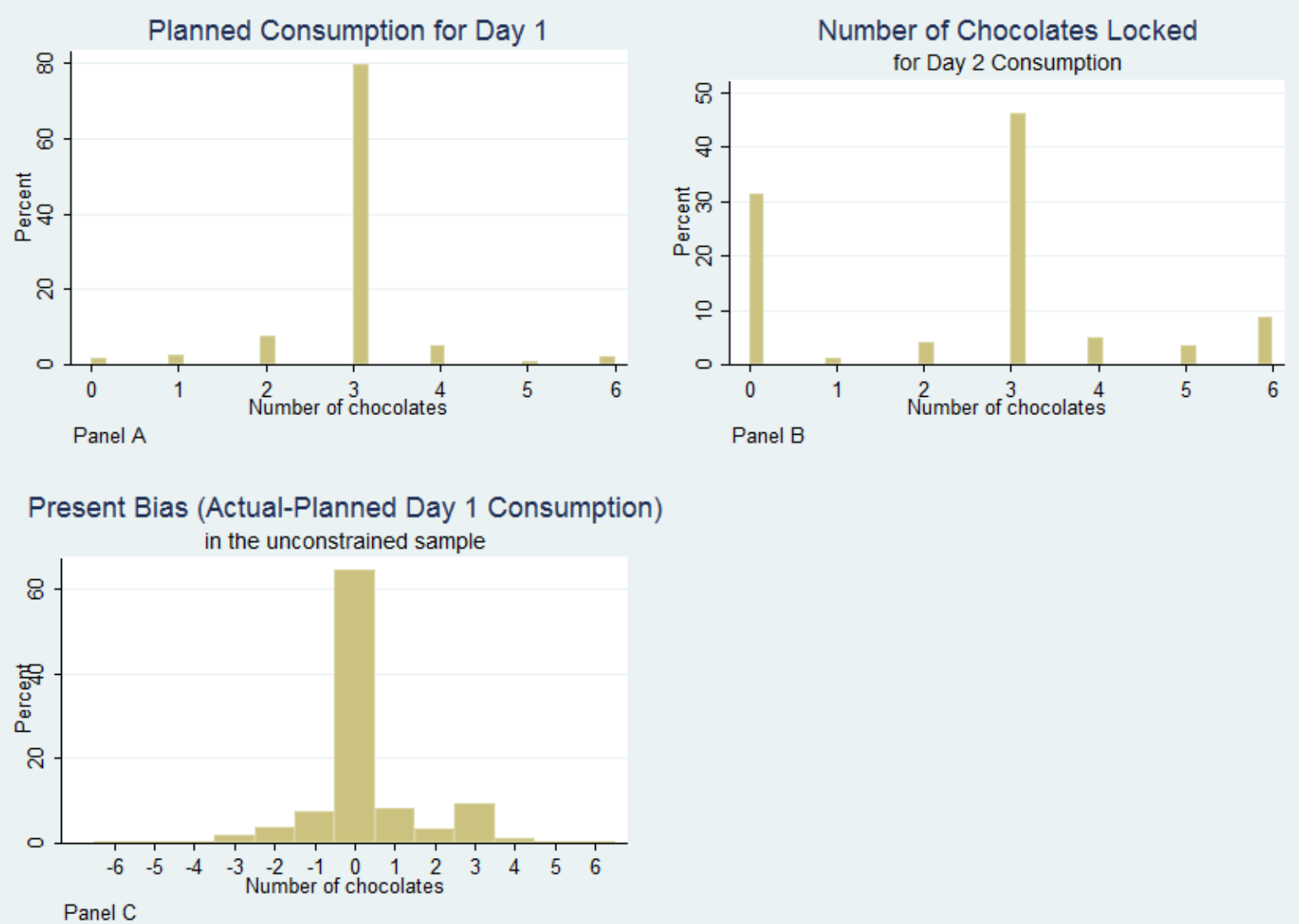

\section{Appendix A:}

\section{Instructions: ${ }^{24}$}

Today, we will play a game. In this game, you will make some choices. The choices you make will determine how many rewards you will get, and when. Please listen very carefully, and do not speak with each other about your choices. There are no right or wrong answers.

Now, please note that we will make a visit to your classroom again, exactly one week from now. When we come, you will each have 6 pieces of chocolate [Show the mini-chocolate]. These are going to be yours to have. But we will first ask you now: how would you like to eat these chocolates over two days? Let's call the day we come here next week, Day 1. On Day 1 your 6 chocolates will arrive. You can eat them on Day 1, or on Day 2, which is the day after. For example, someone could say, "I would like to eat all of my 6 chocolates on Day 1", and none on "Day 2". Another person could say, "I would like to eat 5 of my 6 chocolates on Day 1, and leave one for Day 2". Yet another could say, "I'd like to eat 4 on Day 1, leave 2 for Day 2", another "3 on Day 1, 3 on Day 2", another "2 on Day 1, 4 on Day 2", another could

\footnotetext{
${ }^{24}$ The instructions pertain to the sessions where the plan was incentivized.
} 
say "1 on Day 1, 5 on Day 2", and yet another could say "0 on Day 1, 6 on Day 2". Is there any "right" choice here? No. This is completely up to you to decide, how you want to allocate your chocolates over the two days. Now, we will ask you to make a consumption plan now, about how you would like to allocate your 6 chocolates over the 2 days: the day we come next week, Day 1, and the day after that, Day 2. Please be very careful in making your plan, because there is a small chance that you will not be able to change your decision next week, when the chocolates come. In fact, we will have 9 papers in this bag [show black bag] with the words [FREE TO CHANGE] on it and 1 paper in the bag with the word [CANNOT CHANGE] on it. If the "cannot change" paper is drawn next week, then you have to stick with the plan you make now. So, please make your plan with the knowledge that you could be forced to stick to it. OK? Any questions?

OK. Now, when we come here next week, on Day 1, if FREE TO CHANGE is drawn, which will happen with 9 out of 10 chance, you will be free to decide at that time. What will happen then is the following: we will bring your 6 chocolates. Each of you individually will be asked the following question: how many of your 6 chocolates would you like to eat now? You will take the chocolates you want at that point, and the rest will be left for Day 2. For example, suppose somebody said 4 . She will be able to get 4 , and the 2 that remains, she will get on the next day. Suppose somebody said 3 . She would get 3 , and the 3 that remains, she will get on the next day. If somebody said 6, will she be able to get them all? Yes! Will somebody be able to leave everything to Day 2? Yes! It is completely up to the individual to decide, as she wishes. Depending on how you feel that day, if you want, you can get 6 chocolates, 5 chocolates, 4, 3, 2,1 , or 0 chocolates, this is completely up to you.

Now we will introduce to you a locked box and an unlocked box. Your chocolates will come in the unlocked box, and you are free to take as much as you want on Day 1. However, you can put some of your chocolates in the locked box now. What happens to the chocolates put in this locked box? You will not be able to have them before Day 2 comes, even if you want to. The chocolates you put in the locked box, you can only eat them on Day 2 and not on Day 1. For example: suppose that one person put 4 chocolates in the locked box. These 4 chocolates can only be eaten on Day 2. Can he/she eat 3 chocolates on Day 1 if he/she so desires? No. He/she can only eat up to 2 chocolates, the ones in the unlocked box. OK, so suppose you don't put any chocolates in the locked box. Does this mean that you have to eat all 6 chocolates on Day 1? No. Not locking any chocolates means that you are free to decide however you wish on Day 1. You can decide to eat any amount on Day 1, and leave the rest to Day 2.

Any questions?

Now, please write, on your decision sheets, (1) whether you would like to put any chocolates in the locked box, (2) if so, how many you would like lock.

\section{Multiple Price List Task:}

Subjects are asked to make a decision for each row in each list. Lists are presented separately and sequentially. 
Now vs. 1 week:

\begin{tabular}{|c|c|}
\hline O 2 gifts now & 02 gifts in one week \\
\hline O 2 gifts now & O 3 gifts in one week \\
\hline O 2 gifts now & O 4 gifts in one week \\
\hline ○ 2 gifts now & ○ 5 gifts in one week \\
\hline O 2 gifts now & O 6 gifts in one week \\
\hline ○ 2 gifts now & O 7 gifts in one week \\
\hline ○ 2 gifts now & ○ 8 gifts in one week \\
\hline ○ 2 gifts now & ○ 9 gifts in one week \\
\hline ○ 2 gifts now & O 10 gifts in one week \\
\hline
\end{tabular}

1 week vs. 2 weeks:

\begin{tabular}{|ll|ll|}
\hline$\bigcirc$ & 2 gifts in one week & $\bigcirc$ & 2 gifts in two weeks \\
\hline$\bigcirc$ & 2 gifts in one week & $\bigcirc$ & 3 gifts in two weeks \\
\hline$\bigcirc$ & 2 gifts in one week & $\bigcirc$ & 4 gifts in two weeks \\
\hline$\bigcirc$ & 2 gifts in one week & $\bigcirc$ & 5 gifts in two weeks \\
\hline$\bigcirc$ & 2 gifts in one week & $\bigcirc$ & 6 gifts in two weeks \\
\hline$\bigcirc$ & 2 gifts in one week & $\bigcirc$ & 7 gifts in two weeks \\
\hline$\bigcirc$ & 2 gifts in one week & $\bigcirc$ & 8 gifts in two weeks \\
\hline$\bigcirc$ & 2 gifts in one week & $\bigcirc$ & 9 gifts in two weeks \\
\hline$\bigcirc$ & 2 gifts in one week & $\bigcirc$ & 10 gifts in two weeks \\
\hline
\end{tabular}

\section{Convex Time Budget Task:}

Subjects are asked to choose one of the 6 decisions, in each column (presented as separate decision sheets).

\begin{tabular}{|c|c|c|c|}
\hline $\begin{array}{l}r=0.25, \\
\text { Now vs. } 1 \text { Week }\end{array}$ & $\begin{array}{l}r=0.25 \\
1 \text { Week vs. } 2 \text { Weeks }\end{array}$ & $\begin{array}{l}r=0.5 \\
\text { Now vs. } 1 \text { Week }\end{array}$ & $\begin{array}{l}r=0.5 \\
1 \text { Week vs. } 2 \text { Weeks }\end{array}$ \\
\hline $\begin{array}{l}5 \text { gifts now and } 0 \text { gifts in one } \\
\text { week }\end{array}$ & $\begin{array}{l}5 \text { gifts in } 1 \text { week and } 0 \text { gifts } \\
\text { in two weeks }\end{array}$ & $\begin{array}{l}5 \text { gifts now and } 0 \text { gifts } \\
\text { in one week }\end{array}$ & $\begin{array}{l}5 \text { gifts in } 1 \text { week and } 0 \text { gifts } \\
\text { in two weeks }\end{array}$ \\
\hline $\begin{array}{l}4 \text { gifts now and } 1.25 \text { gifts in } \\
\text { one week }\end{array}$ & $\begin{array}{l}4 \text { gifts in } 1 \text { week and } 1.25 \\
\text { gifts in two weeks }\end{array}$ & $\begin{array}{l}4 \text { gifts now and } 1.5 \\
\text { gifts in one week }\end{array}$ & $\begin{array}{l}4 \text { gifts in } 1 \text { week and } 1.5 \text { gifts } \\
\text { in two weeks }\end{array}$ \\
\hline $\begin{array}{l}3 \text { gifts now and } 2.5 \text { gifts in } \\
\text { one week }\end{array}$ & $\begin{array}{l}3 \text { gifts in one week and } 2.5 \\
\text { gifts in two weeks }\end{array}$ & $\begin{array}{l}3 \text { gifts now and } 3 \text { gifts } \\
\text { in one week }\end{array}$ & $\begin{array}{l}3 \text { gifts in one week and } 3 \text { gifts } \\
\text { in two weeks }\end{array}$ \\
\hline $\begin{array}{l}2 \text { gifts now and } 3.75 \text { gifts in } \\
\text { one week }\end{array}$ & $\begin{array}{l}2 \text { gifts in one week and } 3.75 \\
\text { gifts in two weeks }\end{array}$ & $\begin{array}{l}2 \text { gifts now and } 4.5 \\
\text { gifts in one week }\end{array}$ & $\begin{array}{l}2 \text { gifts in one week and } 4.5 \\
\text { gifts in two weeks }\end{array}$ \\
\hline $\begin{array}{l}1 \text { gift now and } 5 \text { gifts in one } \\
\text { week }\end{array}$ & $\begin{array}{l}1 \text { gift in one week and } 5 \text { gifts } \\
\text { in two weeks }\end{array}$ & $\begin{array}{l}1 \text { gift now and } 6 \text { gifts in } \\
\text { one week }\end{array}$ & $\begin{array}{l}1 \text { gift in one week and } 6 \text { gifts } \\
\text { in two weeks }\end{array}$ \\
\hline $\begin{array}{l}\text { No gifts now and } 6.25 \text { gifts in } \\
\text { one week }\end{array}$ & $\begin{array}{l}\text { No gifts in one week and } \\
6.25 \text { gifts in two weeks }\end{array}$ & $\begin{array}{l}\text { No gifts now and } 7.5 \\
\text { gifts in one week }\end{array}$ & $\begin{array}{l}\text { No gifts in one week and } 7.5 \\
\text { gifts in two weeks }\end{array}$ \\
\hline
\end{tabular}




\section{Early Adolescent Temperament Questionnaire-R, Definitions ${ }^{25}$}

Activation Control: The capacity to perform an action when there is a strong tendency to avoid it.

Attention: The capacity to focus attention as well as to shift attention when desired.

Fear: Unpleasant affect related to anticipation of distress.

Frustration: Negative affect related to interruption of ongoing tasks or goal blocking.

Surgency: The pleasure derived from activities involving high intensity or novelty.

Inhibitory Control: The capacity to plan, and to suppress inappropriate responses.

Aggression: Hostile and aggressive actions, including person- and object-directed physical violence, direct and indirect verbal aggression, and hostile reactivity.

\section{APPENDIX B:}

Table 5B: Relationship with Patience and Time Consistency, Combined Data from MPL and CTB

\begin{tabular}{|c|c|c|c|c|c|}
\hline & $\begin{array}{l}(1) \\
\text { \# of chocolates } \\
\text { planned for } \\
\text { Day1 } \\
\end{array}$ & $\begin{array}{l}\text { (2) } \\
\text { Commitment } \\
\text { take-up }\end{array}$ & $\begin{array}{l}\text { (3) } \\
\text { Commitment } \\
\text { take-up }\end{array}$ & $\begin{array}{l}4) \\
\text { Locked } \\
\text { amount } \\
\text { (all) } \\
\end{array}$ & $\begin{array}{l}5) \\
\text { Locked } \\
\text { amount } \\
\text { (conditional) } \\
\end{array}$ \\
\hline Patience, all tasks & $\begin{array}{l}-0.126 * * * \\
(0.0302)\end{array}$ & $\begin{array}{l}0.317 * * * \\
(0.0816)\end{array}$ & $\begin{array}{l}0.312 * * * \\
(0.0892)\end{array}$ & $\begin{array}{l}0.372 * * * \\
(0.0765)\end{array}$ & $\begin{array}{l}0.199 * * * \\
(0.0567)\end{array}$ \\
\hline Hyperbolic & & & $\begin{array}{l}0.0296 \\
(0.125)\end{array}$ & $\begin{array}{l}0.0756 \\
(0.111)\end{array}$ & $\begin{array}{l}0.0849 \\
(0.0842)\end{array}$ \\
\hline Hypobolic & & & $\begin{array}{l}-0.203 * * \\
(0.100)\end{array}$ & $\begin{array}{l}-0.297 * * * \\
(0.0849)\end{array}$ & $\begin{array}{l}-0.206 * * * \\
(0.0613)\end{array}$ \\
\hline Male & $\begin{array}{l}0.0787 * * * \\
(0.0300)\end{array}$ & $\begin{array}{l}-0.0893 \\
(0.0818)\end{array}$ & $\begin{array}{l}-0.0868 \\
(0.0835)\end{array}$ & $\begin{array}{l}0.0350 \\
(0.0721)\end{array}$ & \\
\hline Constant & $\begin{array}{l}2.974 * * * \\
(0.0240)\end{array}$ & $\begin{array}{l}0.655 * * * \\
(0.0717)\end{array}$ & $\begin{array}{l}0.691 * * * \\
(0.0911)\end{array}$ & $\begin{array}{l}2.203 * * * \\
(0.0774)\end{array}$ & $\begin{array}{l}3.391 * * * \\
(0.0511)\end{array}$ \\
\hline $\begin{array}{l}\text { Observations } \\
\mathrm{R}^{2}\end{array}$ & $\begin{array}{l}2,793 \\
0.009\end{array}$ & 2,793 & 2,674 & $\begin{array}{l}2,663 \\
0.016\end{array}$ & $\begin{array}{l}1,813 \\
0.015\end{array}$ \\
\hline
\end{tabular}

Note: "Patience, all tasks" is a dummy variable that takes the value of 1 if the student made a patient choice in the relevant task (either MPL or CTB), and 0 otherwise. Columns 1, 4 and 5 report OLS regressions. Columns 2 and 3 report logit regressions. Robust standard errors in parentheses. $* * * \mathrm{p}<0.01, * * \mathrm{p}<0.05, * \mathrm{p}<0.1$

\footnotetext{
${ }^{25}$ Taken from "http://www.bowdoin.edu/ sputnam/rothbart-temperament-questionnaires/instrumentdescriptions/early-adolescent-temperament.html"
} 